\title{
ガーベラ切り花日持ち品種間差における生け水中の細菌の関与
}

\author{
外岡 慎 ${ }^{1 \mathrm{a} *} \cdot$ 本間義之 $^{1} \cdot$ 貫井秀樹 $^{1} \cdot$ 市村一雄 ${ }^{2}$ \\ 1 静岡県農林技術研究所 438-0803 静岡県磐田市富丘 \\ 2 農業・食品産業技術総合研究機構野菜花き研究部門 305-0852 茨城県つくば市藤本
}

\section{The Effects of Bacteria in Vase Water on the Vase Life of Cut Gerbera Cultivars}

\author{
Makoto Tonooka ${ }^{1 \text { a* }}$, Yoshiyuki Homma ${ }^{1}$, Hideki Nukui ${ }^{1}$ and Kazuo Ichimura ${ }^{2}$ \\ ${ }^{I}$ Shizuoka Prefectural Research Institute of Agriculture and Forestry, Iwata, Shizuoka 438-0803 \\ ${ }^{2}$ Institute of Vegetable and Floriculture Science, NARO, Tsukuba, Ibaraki 305-0852
}

\begin{abstract}
A factor that shortens the vase life of cut gerbera was investigated. When cut 'Minou' gerbera flowers were placed in water with a relatively high bacterial concentration, the vase life was markedly shortened. An experiment using vase water of cut 'Picture Perfect' and 'Pinta' revealed a correlation between the turbidity and bacterial number, suggesting that an increase in the turbidity of vase water is attributable to bacterial proliferation. There were differences among seven cultivars in the turbidity of vase water. Treatment with an isothiazolinonic germicide markedly extended the vase life of some cultivars, such as 'Picture Perfect', in which the turbidity of vase water was relatively high. In cut 'Minou', turbidity of vase water increased with time, and treatment with the germicide almost completely suppressed this increase. Treatment with the germicide increased water uptake of cut flowers and suppressed any decrease in the fresh weight. These results suggest that there is variation among cultivars in the turbidity of vase water, which is closely associated with the vase life of cut gerbera.
\end{abstract}

Key Words : germicide, longevity

キーワード：品質保持期間，抗菌剂

\begin{abstract}
緒 言
ガーベラ（Gerbera L.）は，温帯打よび熱帯アジア，ア フリカの山地に約 400 種が分布する温帯性の多年草であ る. 一般にガーベラとして栽培されているのは，南アフリ カのトランスバール原産の G. viridifolia Schultz-Bip. 抢よび その変種, 鮮赤色の G. aurantiaca Schultz-Bip. が繰り返し 交雑された園芸品種である（松川，1988）。ガーベラは, 品種数が多く，花色や花形が豊富で，年間を通して出荷量 が安定した人気のある切り花品目である。平成 28 年産に 抢けるガーベラ切り花の出荷量は 165,300 千本，らち静岡 県は 62,900 千本（農林水産省, 2018）と $38 \%$ のシェアを占 め, 静岡県ではキクに次ぐ主要切り花に位置づけられてお り，県内の主要産地は，浜松市，牧之原市，島田市などで ある.
\end{abstract}

2018 年 3 月 16 日 受付. 2018 年 8 月 7 日 受理.

本研究は, 新たな農林水産政策を推進する実用技術開発事業 「花持ち保証に対応した切り花品質管理技術の開発（課題番号 22008）」の一環として行わ机た. また，本研究の一部は園芸学 会平成 24 年度春季大会で発表した。

* Corresponding author. E-mail: makoto1_tonooka@pref.shizuoka.lg.jp

a 現在 : 静岡県経済産業部農業局地域農業課
多くの消費者は，切り花を購入する際に日持ちを重視 している（市村，2011; 今西ら，1992）。ガーベラ切り花は 日持ちが短いとされることが多いが，10日以上と比較的 長いことを示寸報告もある (Jones・Hill, 1993; 小笠原ら， 2012）。ガーベラ切り花が観賞価値を失う症状には，花弁 が萎孔る場合と花茎が曲がる場合がある．ガーベラ切り花 を水替えすることなく生け続けると，生けた水が白濁して 悪臭を放ち, 生け水中もしくはその直上部の花茎が腐敗す ることがある，花茎が曲がる場合，この腐敗した部位もし くは花首から $10 \mathrm{~cm}$ 程度下の部位のいずれかで曲がること が多いが調查例はない。また $660 \mathrm{~nm}$ の濁度は細菌数と相 関が高いことが報告されて打り（佐藤ら，1983），水の濁 りは細菌に由来することが示唆されている.

バラの切り花では, 日持ちが短縮する要因として細菌 の関与が明らかにされて扮り, 生け水中の細菌数濃度が $10^{6} \mathrm{CFU} \cdot \mathrm{mL}^{-1}$ 以上では日持ちが著しく短くなること (Jones・Hill, 1993)，生け水の細菌の増殖は導管閉塞を引 き起こし，日持ちを短縮させること（Put・Jansen, 1989）， また細菌は導管内にも増殖すること（van Doorn ら，1989， 1991）が報告されている。 また，ガーベラ切り花に拈いて も，日持ちが短い理由として水分状態が悪化しやすいこと が指摘されて抒り（van Meeteren, 1978），バラと同様に細 
菌の増殖による導管閉塞が切り花の水分状態の悪化に寄与 することが示唆されている（Clerkx ら，1989; van Doorn・ de Witte, 1994).

ここでは，ガーベラの日持ちが短くなる原因と考えられ る花茎が腐り曲がる症状に着目し，ガーベラ切り花の日持 ちと生け水中の細菌との関係について検討した.

\section{材料および方法}

\section{1. ガーベラの日持ちの品種間差異（実験 1)}

2009 年 6 月 18 日に管状花の外側 1 列が開花した状態で 收穫した“ピンタ’, ‘ブラバ’, ‘バナナ’, ‘ティム’, ‘ミ, ウ’, ‘キムシ一’扎よび ‘ピクチャーパーフェクト’を花 茥長が $40 \mathrm{~cm}$ になるよら調整したあと, 対照区として蒸留 水，抗菌剂添加区としてイソチアゾリン系抗菌剂（レ ジェンド MK, 有効成分として $5.7 \mathrm{mg} ・ \mathrm{~L}^{-1}$ 5-クロロ-2-メ チル-4-イソチアゾリン-3-オン拉よび $2 \mathrm{mg} ・ \mathrm{~L}^{-1} 2$-メチル-4イソチアゾリン-3-オンを含む, ロームアンドハースジャ パン）を蒸留水に添加して濃度を $0.25 \mathrm{~mL} ・ \mathrm{~L}^{-1}$ に調整した 溶液 $100 \mathrm{~mL}$ を入れた試験管に 1 本ずつ生けた。 1 処理区 当たり 9 本を供試した. 生け水の濁度は, 目視で複数の品 種で濁りが確認された処理開始後 10 日目の蒸留水区に ついて, 分光光度計 (UV150-02, (株) 島津製作所）によ り $660 \mathrm{~nm}$ の吸光度を測定することによって調査した. 日 持ち調查は, 室温 $23^{\circ} \mathrm{C}$, 相対湿度 $70 \%, 12$ 時間明条件 (6:00〜 18:00), PPFD $10 \mu \mathrm{mol} \cdot \mathrm{m}^{-2} \cdot \mathrm{s}^{-1}$ に制御した恒温庫 内で行った. 日持ち期間は, 花茎の曲がり, 花弁の脱落, 花首直下の折れ, 花弁の萎れ, 花弁の脱色のいずれかの症 状が発生するまでとした。

\section{2. 生け水の白濁と生け水中の細菌数との関係（実験 2)}

供試品種は“ピンタ’と‘ピクチャーパーフェクト’を 用いた。 2010 年 10 月 1 日に収穫した“ピンタ’ と ‘於 チャーパーフェクト’を花茥長が $40 \mathrm{~cm}$ になるよら調整し た後, $200 \mathrm{~mL}$ の蒸留水を入れた容器に 4 本ずつ生けた. 処理開始後 7 日目に生け水の濁度および生け水中の細菌数 を調査した. 生け水中の細菌数は, 生け水を滅菌水で希釈 後, 希釈液の $100 \mu \mathrm{L}$ を Yeast Pepton培地（酵母エキス $5 \mathrm{~g} ・ \mathrm{~L}^{-1}$, ペプトン $5 \mathrm{~g} ・ \mathrm{~L}^{-1}$, 塩化ナトリウム $5 \mathrm{~g} ・ \mathrm{~L}^{-1}$, 寒 天 $\left.15 \mathrm{~g} ・ \mathrm{~L}^{-1}, \mathrm{pH} 7\right)$ を用い, $25^{\circ} \mathrm{C}$ 暗黒条件で 5 日間培養後, コロニー数を調査した. 日持ち調査拈よび恒温庫内の条件 は，実験 1 と同様に設定した.

3. 生け水の状態が日持ちと日持ち終了様相に及ぼす影響 （実験 3）

供試品種は“ミノウ’を用いた。供試した生け水は, 対 照区として蒸留水，水質悪化区としてあらかじめガーベラ を生け続け白濁した水を用いた。生け花前に白濁した生け 水の濁度と細菌数を調査した. 細菌数は, 生け水を滅菌水 で希釈後, 希釈液の $1 \mathrm{~mL}$ をペトリィルム $\mathrm{AC}$ プレート (スリーエムジャパン (株)) で， $35^{\circ} \mathrm{C}$ 暗黒条件で 2 日間培 養後, コロニー数を調査した.
2011 年 10 月 7 日に収穫した“ミノウ’を花茥長が $40 \mathrm{~cm}$ になるよら調整し，各区とも生け水を $100 \mathrm{~mL}$ を入れた直 径 $40 \mathrm{~mm}$, 長さ $130 \mathrm{~mm}$ の試験管に 1 本ずつ生けた. 1 処 理区当たり 10 本を供試した，処理開始時と 5 日目に，切 り花重と溶液重を調査した。 な抏，併せてガーベラ切り花 を処理することなく，溶液のみ入れた試験管を準備し，自 然に蒸散した溶液量を調査した。相対新鮮重は，処理開始 時の切り花重を 100 として算出した. 吸水量は, 処理開始 時点から5日目までに減少した溶液重から自然に蒸散した 溶液重を差し引き，処理開始時の切り花重 $1 \mathrm{~g}$ 当たりで算 出した。恒温庫内の条件は, 実験 1 と同様に設定した.

\section{4. 抗菌剤処理が生け水の白濁および日持ちに及ぼす影響 (実験 4)}

供試品種は“ミノウ’を用いた。2009年 8 月 1 日に収穫 しだミノウ’を花茥長が $40 \mathrm{~cm}$ になるよら調整した後, 対照区として蒸留水，抗菌剂添加区としてイソチアゾリン 系抗菌剂 $0.25 \mathrm{~mL} ・ \mathrm{~L}^{-1}$ を添加した蒸留水 $100 \mathrm{~mL}$ をれた 試験管に 1 本ずつ生けた。 日持ち調査は, 1 処理区当たり 8 本を供試した。処理開始時から 2 日間隔で 12 日目まで, 切り花重と溶液重を調査した。 な拈, 併せてガーベラ切り 花を処理することなく, 溶液のみ入れた試験管を準備し, 自然に蒸散した溶液量を調査した。相対新鮮重は，処理開 始時の切り花重を 100 として算出した。吸水量は，処理開 始時点から 8 日目までに減少した溶液重から自然蒸散した 溶液重を差し引き，処理開始時の切り花重 $1 \mathrm{~g}$ 当たりで算 出した。処理開始後 4 日目，8 日目および 12 日目に生け水 の濁度を調査した。恒温庫内の条件は，実験 1 と同様に設 定した.

\section{結果 \\ 1. ガーベラの日持ちの品種間差異（実験 1)}

処理開始後 10 日目の水の濁度は, ‘ピンタ’ で 0.003 , ‘ブ ラバ’で 0.005 , ‘バナナ’ で 0.018 と低く, これら 3 品種に 比ベ“ピクチャーパーフェクト’では 0.171 と有意に高い ことが示された(第1図).

蒸留水に生けた切り花の日持ちは, “ピンタ’で18.0日 と最も長く，次いで‘ブラバ’の 16.0 日であった。最も日 持ちが短かったのは“ピクチャーパーフェクト’で 10.3 日, 次いで‘キムシー’の11.8日であった（第1表).

抗菌剂を添加した水に生けることで，生け水の濁りの発 生は抑制された。 7 品種中 5 品種で日持ちは有意に長く なったが, ‘ブラバ’と“バナナ’では有意差は認められな かった（第 1 表）.

蒸留水に生けた切り花の日持ちが最も長かった“ピン 夕’では，9本中花茎が腐るものはなかった．花茎の曲が りにより観賞価値を失ったものは 1 本と少なく, 残り 8 本 は花弁の萎れで観賞価值を失った。抗菌剤を添加した水に 生けた切り花では，花菱が腐るものはなく，9本すべてが 花弁の萎れで観賞価值を失った（第 1 表）。な拈，蒸留水 


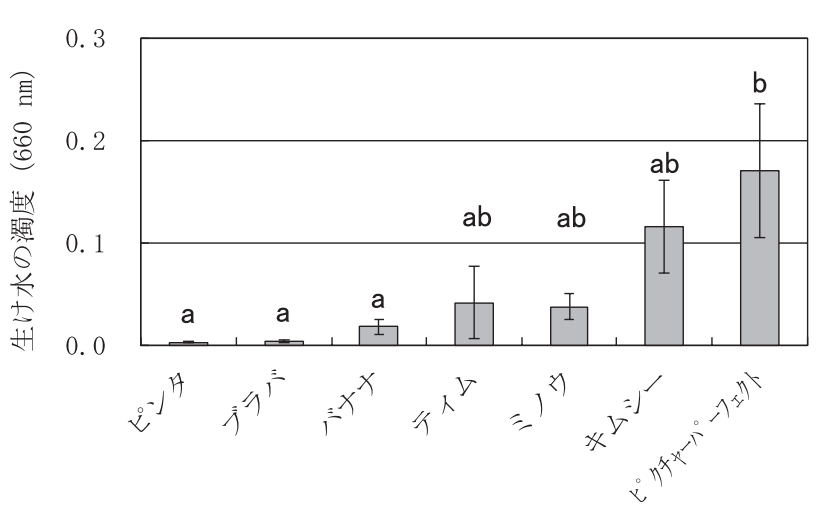

第1図 ガーベラ 7 品種における生け水の濁度（実験 1) 生け水の濁度は処理開始後 10 日目に測定 図中の縦線は標準誤差を示す $(n=9)$

異符号間は Tukey-Kramer 法により 5\%水準で有意差 があることを示す

に生けた切り花で, 花茎が曲がる症状で観賞価值を失った 1 本の平均の日持ちは 17.0 日, その生け水の濁度は 0.009 であった。 それ以外の症状で観賞価值を失った 8 本の平均 の日持ちは 18.1 日，その生け水の濁度の平均值は 0.003 で あった。

蒸留水に生けた切り花の日持ちが最も短かった ‘於 チャーパーフェクト’ では, 9 本中花茎の腐りが 4 本発生 し, この 4 本すべてが花茎の曲がりにより観賞価值を失っ た. 残りは花弁の萎れで 4 本, 花首の折れで 1 本が観賞価
值を失った，抗菌剤を添加した水に生けた切り花では，花 茥の腐りや曲がりの発生はなく, 花首の折れで7本，花弁 の萎れで 1 本，花弁の脱落で 1 本が観賞価值を失った（第 1 表)。な挔, 蒸留水に生けた切り花で, 花茎が曲がる症 状で観賞価值を失った 4 本の平均の日持ちは 4.8 日，その 生け水の濁度の平均值は 0.341 であった。 それ以外の症状 で観賞価值を失った 5 本の平均の日持ちは 14.8 日，その 生け水の濁度の平均值は 0.036 であった。

蒸留水に生けた切り花の日持ちが ‘ピクチャーパーフェ クト’ に次いで短い ‘キムシー’ では, 9 本中花茎の腐り が 4 本発生し, このらち花茎の曲がりで 3 本, 花弁の萎机 で 1 本が観賞価値を失った。花茎の腐りが発生しなかった 残り 5 本は, 花弁の萎れで 2 本, 花弁の脱色で 2 本, 花首 の折れで 1 本が観賞価值を失った。抗菌剤を添加した水 に生けた切り花では, 花茎の腐りや曲がりの発生はなく, 9 本すべてが花弁の脱色で観賞価値を失った（第 1 表）。な 扣, 蒸留水に生けた切り花で, 花茎が腐り曲がる症状で観 賞価值を失った 3 本の平均の日持ちは 6.7 日，その生け水 の濁度の平均値は 0.266 であった。それ以外の症状で観賞 価值を失った 6 本の切り花の平均の日持ちは14.3日，そ の生け水の濁度の平均値は 0.042 であり, 生け水の濁度が 高いと花茎が曲がる症状の発生が多く, 日持ちも短いこと が示された.

\section{2. 生け水の白濁と生け水中の細菌数との関係（実験 2)}

実験 1 で, 蒸留水に生けた切り花の日持ちが最も長かっ

第 1 表 ガーベラ 7 品種に拈ける抗菌剤処理が日持ちに及ぼす影響（実験 1)

\begin{tabular}{|c|c|c|c|c|c|c|c|c|}
\hline \multirow{2}{*}{ 品種 } & \multirow{2}{*}{ 生け水 ${ }^{z}$} & \multirow{2}{*}{$\begin{array}{c}\text { 日持ち日数 } \\
\text { (日) }\end{array}$} & \multicolumn{5}{|c|}{ 観賞価值を失った症状（本） } & \multirow{2}{*}{$\begin{array}{c}\text { 花茥の腐り } \\
\text { (本) }\end{array}$} \\
\hline & & & 花茎の曲がり & 花弁の萎れ & 花首の折れ & 花弁の脱落 & 花弁の脱色 & \\
\hline \multirow{2}{*}{ ピンタ } & 蒸留水 & $18.0 * * \mathrm{y}$ & 1 & 8 & 0 & 0 & 0 & 0 \\
\hline & 抗菌剂 & 19.4 & 0 & 9 & 0 & 0 & 0 & 0 \\
\hline \multirow{2}{*}{ ブラバ } & 蒸留水 & $16.0 \mathrm{~ns}$ & 2 & 7 & 0 & 0 & 0 & 0 \\
\hline & 抗菌剤 & 15.8 & 0 & 9 & 0 & 0 & 0 & 0 \\
\hline \multirow{2}{*}{ バナナ } & 蒸留水 & $13.9 \mathrm{~ns}$ & 0 & 5 & 0 & 4 & 0 & 0 \\
\hline & 抗菌剤 & 14.6 & 1 & 1 & 4 & 3 & 0 & 0 \\
\hline \multirow{2}{*}{ ティム } & 蒸留水 & $12.8 *$ & 4 & 5 & 0 & 0 & 0 & 1 \\
\hline & 抗菌剂 & 14.4 & 0 & 7 & 2 & 0 & 0 & 0 \\
\hline \multirow{2}{*}{ ミノウ } & 蒸留水 & $12.4 * *$ & 1 & 4 & 3 & 1 & 0 & 1 \\
\hline & 抗菌剂 & 14.4 & 0 & 0 & 5 & 4 & 0 & 0 \\
\hline \multirow{2}{*}{ キムシー } & 蒸留水 & $11.8 *$ & 3 & 3 & 1 & 0 & 2 & 4 \\
\hline & 抗菌剂 & 16.0 & 0 & 0 & 0 & 0 & 9 & 0 \\
\hline \multirow{2}{*}{ ピクチャーパーフェクト } & 蒸留水 & $10.3 * *$ & 4 & 4 & 1 & 0 & 0 & 4 \\
\hline & 抗菌剤 & 16.6 & 0 & 1 & 7 & 1 & 0 & 0 \\
\hline \multirow{3}{*}{ 分散分析 ${ }^{x}$} & 品 種 & ** & & & & & & \\
\hline & 生け水 & $* *$ & & & & & & \\
\hline & 交互作用 & $* *$ & & & & & & \\
\hline
\end{tabular}

z 抗菌剂はイソチアゾリン系抗菌剂を蒸留水に溶かした溶液（濃度：0.25 $\mathrm{mL} ・ \mathrm{~L}^{-1}$ )

${ }^{\mathrm{y}} \mathrm{t}$ 検定で，各品種生け水の違いにより，**は $1 \%$ 水準で，*は $5 \%$ 水準で有意差あり， ns は有意差なし

$\mathrm{x} * *$ は分散分析で，1\%水準で有意差あり 

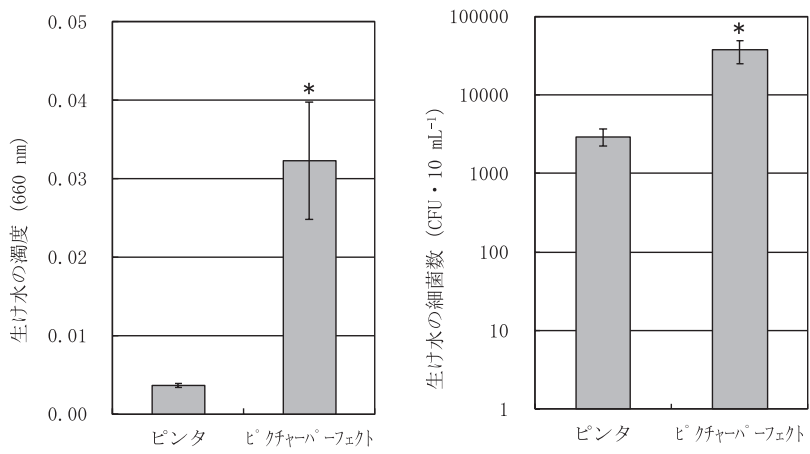

第2図 ガーベラ ‘ピンタ’と ‘ピクチャーパーフェクト’ 切 り花に打情生け水の濁度と細菌数（実験 2）

生け水の濁度と細菌数は処理開始後 7 日目に測定 図中の縦線は標準誤差を示す $(n=3)$

*は t 検定で，5\%水準で有意差があることを示す

た“ピンタ’と最も短かっだピクチャーパーフェクト’ を供試した. 処理開始後 7 日目の生け水の濁度は, “ピン 夕’に打いて 0.004 と低く, “ピクチャーパーフェクト’に 打いて 0.032 と高かった。一方, 処理開始後 7 日目の細 菌数は, ‘ピンタ' で $3.0 \times 10^{3} \mathrm{CFU} \cdot \mathrm{mL}^{-1}$ と少なく, ‘ピク チャーパーフェクト’で $3.7 \times 10^{4} \mathrm{CFU} \cdot \mathrm{mL}^{-1}$ と多かった (第 2 図).

\section{3. 生け水の状態が日持ちと日持ち終了様相に及ぼす影響 (実験 3)}

実験 1 亿扣いて, 蒸留水に生けた 7 品種のらち, 日持ち, 生け水の濁度とも中間的な值を示した“ミノウ’を用いた。

蒸留水に生けた切り花では, 白濁した水に生けた切り花 より吸水量が多く，5日目の相対新鮮重は高かった。蒸留 水に生けた切り花では，10本中花茎が腐るものはなかっ た。また 10 本中花茎の曲がりにより観賞価値を失ったも のは2本と少なく，残りは花弁の萎れで 3 本，花首の折れ で 3 本，花弁の脱落で 2 本が観賞価值を失い，日持ちは 15.8 日と長かった(第2 表).

白濁した生け水の濁度は 0.238 , 細菌数は $10^{8} \mathrm{CFU} \cdot \mathrm{mL}^{-1}$ であった，白濁した水に生けた切り花では，10本すべて の花茎が腐り，花茎の曲がりにより観賞価値を失ったもの は9本と多く, 残りは花弁の萎孔で1本が観賞価值を失い, 日持ちは 5.1 日と短かった（第2表）。

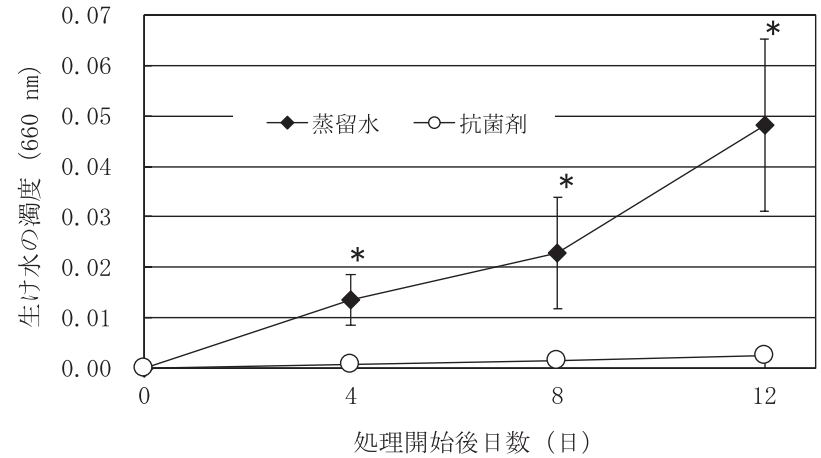

第3 図抗菌剂処理の有無が ‘ミノウ’ 切り花の生け水の濁 度に及ぼす影響（実験 4)

図中の縦線は標準䛊差を示す $(\mathrm{n}=8)$

*はt 検定により $5 \%$ 水準で有意差があることを示す

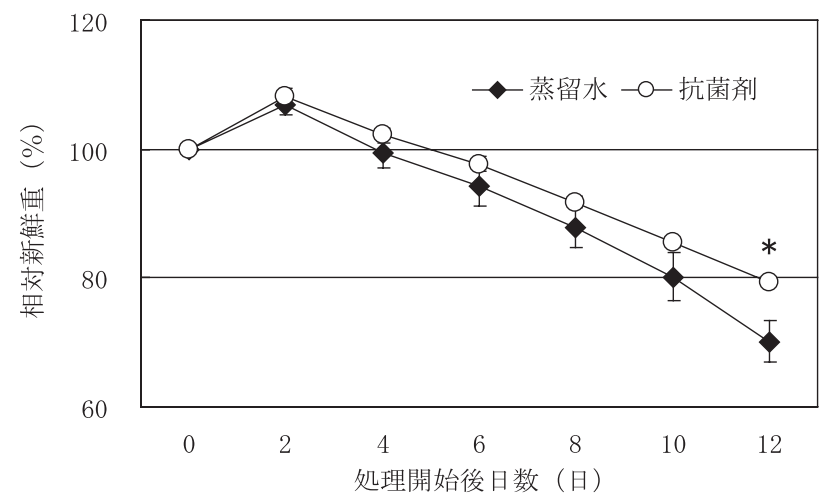

第 4 図 抗菌剂処理の有無が ‘ミノウ’ 切り花の処理開始後 の相対新鮮重に及ぼす影響（実験 4)

図中の縦線は，標準誤差を示す $(\mathrm{n}=8)$

*はt検定により $5 \%$ 水準で有意差があることを示す

\section{4. 抗菌剤処理が生け水の白濁および日持ちに及ぼす影響 (実験 4)}

実験 3 と同様に“ミノウ’を用いた．生け水の濁度は, 蒸留水に生けた切り花では処理開始後日数の経過により高 くなったが，抗菌剤を添加した切り花では低く維持された (第3 図)。相対新鮮重は，処理開始後2日目までは増加し, その後 12 日目まで緩やかに減少した。蒸留水に生けた切 り花よりも抗菌剤を添加した水に生けた切り花の方が，よ り緩やかに減少する傾向を示した（第 4 図），処理開始後 8 日目までの吸水量は，抗菌剤を添加した水に生けた切り

第2 表 生け水の状態がガーベラ“ミノウ’切り花の観賞価值を失った症状と日持ちに及汸す影響（実験 3）

\begin{tabular}{|c|c|c|c|c|c|c|c|c|}
\hline \multirow{2}{*}{ 生け水 } & \multirow{2}{*}{$\begin{array}{c}\text { 吸水量 }^{\mathrm{z}} \\
\left(\mathrm{g} \cdot \mathrm{g}^{-1} \mathrm{FW}\right)\end{array}$} & \multirow{2}{*}{$\begin{array}{c}\text { 相対新鮮重 }{ }^{\mathrm{y}} \\
(\%)\end{array}$} & \multirow{2}{*}{$\begin{array}{c}\text { 日持ち日数 } \\
\text { (日) }\end{array}$} & \multicolumn{4}{|c|}{ "観賞価値を失った症状（本） } & \multirow{2}{*}{$\begin{array}{c}\text { 花茎の腐り } \\
\text { (本) }\end{array}$} \\
\hline & & & & 花茥の曲がり & 花弁の萎れ & 花首の折れ & 花弁の脱落 & \\
\hline 蒸留水 & 0.73 & 115 & 15.8 & 2 & 3 & 3 & 2 & 0 \\
\hline 白濁水 & 0.53 & 100 & 5.1 & 9 & 1 & 0 & 0 & 10 \\
\hline $\mathrm{t}$ 検定 ${ }^{x}$ & $* *$ & $* *$ & $* *$ & & & & & \\
\hline
\end{tabular}

$\mathrm{z}$ 処理開始時の植物体 $1 \mathrm{~g}$ 当たりの処理開始から5 日間の平均吸水量

$\mathrm{y}$ 処理開始時を 100 とした処理開始後 5 日目の相対新鮮重

${ }^{\mathrm{x}} \mathrm{t}$ 検定で，**は $1 \%$ 水準で有意差あり 
第 3 表 抗菌剂処理の有無がガーベラ“ミノウ’切り花の観賞価値を失った症状と日持ちに及ぼす 影響（実験 4）

\begin{tabular}{|c|c|c|c|c|c|c|}
\hline \multirow{2}{*}{ 生け水 } & \multirow{2}{*}{$\begin{array}{c}\text { 吸水量 }{ }^{\mathrm{z}} \\
\left(\mathrm{g} \cdot \mathrm{g}^{-1} \mathrm{FW}\right)\end{array}$} & \multirow{2}{*}{$\begin{array}{c}\text { 日持ち日数 } \\
\text { (日) }\end{array}$} & \multicolumn{3}{|c|}{ 観賞価値を失った症状（本） } & \multirow{2}{*}{$\begin{array}{c}\text { 花茎の腐り } \\
\text { (本) }\end{array}$} \\
\hline & & & 花茥の曲がり & 花弁の萎机 & 花弁の脱落 & \\
\hline 蒸留水 & 1.70 & 12.0 & 2 & 1 & 5 & 1 \\
\hline 抗菌剤 & 2.14 & 14.5 & 0 & 4 & 4 & 0 \\
\hline $\mathrm{t}$ 検定 ${ }^{y}$ & $*$ & $*$ & & & & \\
\hline
\end{tabular}

$\mathrm{z}$ 処理開始時の植物体 $1 \mathrm{~g}$ 当たりの処理開始から 8 日間の平均吸水量

${ }^{\mathrm{y}} \mathrm{t}$ 検定で，*は 5\%水準で有意差あり

花が蒸留水に生けた切り花に比べ多かった (第3 表)。日 持ちは, 抗菌剂を添加した水に生けた切り花では 14.5 日 と, 蒸留水に生けた切り花の 12.0 日に比べ有意に長かっ た（第3表）.

蒸留水に生けたものでは, 花茎の曲がりにより観賞価値 を失ったものが 2 本, このらち 1 本で花茎の腐りが発生し た. 残りは花弁の脱落で 5 本, 花弁の萎孔で 1 本が観賞価 值を失ったが，この6本に花茎の腐りは発生しなかった。 抗菌剂を添加した水に生けた切り花では, 花茎が腐るもの はなく, 花弁の萎れで 4 本, 花弁の脱落で 4 本が観賞価值 を失った（第 3 表）.

\section{考察}

ガーベラ切り花の日持ちには品種間差があることが報告 されて抢り（van Doorn・de Witte, 1994），品種間差をもた らす原因は細菌に対する感受性であることが示唆されてい る. 本研究ではガーベラ 7 品種を供試し, 切り花の日持ち に及ぼす抗菌剤の効果に品種間差があること（第 1 表）に 加えて, 生け水の濁度预よび細菌の増殖にも品種間差があ ること（第 1 図，第 2 図）も新たに明らかにした． $660 \mathrm{~nm}$ の濁度は細菌数と相関が高いことが報告されている（佐藤 ら，1983）が，濁度が高い品種で生け水中の細菌数が多 かった（第２図）。また，生け水の濁度が高い品種では， 花茎の曲がりや腐りにより観賞価值を失ら本数が多く, 日 持ちが短かった (第 1 表)。 これらから，ガーベラ切り花 に扔いて，生け水中に増殖する細菌数は品種により異な り，細菌の增殖しやすさが日持ちを短くする原因であると 考えられた。

ガーベラ切り花の日持ちが短い理由は, 水分状態が悪 化しやすいことであり（van Meeteren, 1978）, 生け水中に 増殖した細菌が原因であることが示唆された（Clerkxら， 1989; van Doorn・de Witte, 1994). 本研究では, 細菌数濃 度が $10^{8} \mathrm{CFU} \cdot \mathrm{mL}^{-1}$ で，その濁度が高い水に，花茎長を $40 \mathrm{~cm}$ に調整したガーベラを生けたところ, 供試した 10 本 すべての切り花で花茎が腐り, 9 本で花茎の曲がりが発生 し, 日持ちが短くなった (第 2 表)。ささらに生け水の白濁 が起こりやすい'ピクチャーパーフェクト’では（第1 図), 蒸留水に生けたもので 10 本中 4 本が, 花茎が腐り曲 がる症状で観賞価值を失った，抗菌剂に生けたものでは花
茎の腐り曲がる症状の発生がなく，日持ちが長くなった (第 1 表)。これらの結果は，ガーベラ切り花の日持ちが短 くする花茎が腐り曲がる症状は, 生け水中に増殖した細菌 が原因である可能性が高いことが示唆された。

切り花を蒸留水に生けた場合は，処理開始後日数の経過 に伴い, 生け水の濁度が高くなり, 生け花後時間の経過と ともに水分状態が悪化していることが示された。一方，抗 菌剤を添加した水に生けた場合，その生け水の濁度は低く 推移し（第3 図），水分状態の悪化を抑制していた。抗菌 剂を添加した水に生けた切り花は，蒸留水に生けたものに 比べ, ガーベラ切り花の吸水量が増加し, 処理開始後の相 対新鮮重が高く維持され，日持ちが長くなった（第 4 図, 第 3 表)，実験 1 亿打いても，蒸留水に生けた水の濁度が 高い品種では，抗菌剂を添加した水に生けることにより， 花茎の曲がりや腐りにより観賞価值を失う症状の発生がな く，日持ちが長くなった（第 1 表）.

本研究では，花茎の曲がりや腐りの発生が，日持ちを短 くする重要な要因となっていることに着目し，生け水中の 細菌と日持ちとの関係を明らかにした。 しかし，ガーベラ 切り花の日持ちを短縮する生け水中の細菌が増殖する原因 は明らかとなっていない，このため，その原因について検 討する必要がある。 また本研究では, 蒸留水に生けた切り 花のうち実験 1 で ‘ピンタ’が 1 本, 実験 3 で‘ミノウ’ が 2 本, 実験 4 で‘ミノウ’が 1 本，花茎が腐ることなく， 花茎が曲がる症状で観賞価値を失った，このことから，花 茎が曲がる症状には花茎の腐りを伴わない症状もあると考 えられ，こうした症状が発生する原因について検討する必 要があると考兄らる。

\section{摘 要}

ガーベラ切り花の日持ち短縮に関与する原因を検討し た. ガーベラ ‘ミノウ’切り花を細菌濃度が上昇した白濁 水に生けると, 花茎の曲がりが促進され日持ちが著しく短 縮した. ‘ピクチャーパーフェクト’と“ピンタ’の生け水 を用いた実験は濁度と細菌濃度との間には相関があること を示した．この結果は生け水の濁度の上昇は細菌の増殖に よることを示唆している. ガーベラ7 品種切り花に扔いて, 生け水の濁度には著しい品種間差があった。 ‘ピクチャー パーフェクト’をはじめとして濁度が高い品種では, イソ 
チアゾリン系抗菌剂処理による日持ち延長効果が大きかっ た. ‘ミノウ’では，時間の経過に伴い生け水の濁度が上 昇したが，抗菌剂処理により濁度の上昇が完全に抑制され た. また, 抗菌剤処理は吸水量を増加させ, 切り花新鮮重 の低下を抑制した. 以上の結果から，ガーベラ切り花を生 けた水の濁度には品種間差があり, 生け水の濁度はガーベ ラ切り花の日持ちと密接に関係していることが示唆された.

\section{引用文献}

Clerkx, A. C. M., A. Boekestein and H. M. C. Put. 1989. Scanning electron microscopy of the stem of cut flowers of Rosa cv. Sonia and Gerbera cv. Fleur. Acta Hortic. 261: 97-105.

市村一雄. 2011. 切り花の品質保持. p. 17-19. 筑波書房. 東京.

今西弘子・米沢富土雄 - 今西英雄. 1992. 花に対する花店 利用者の意識. 園学雑. 60: 981-987.

Jones, R. B. and M. Hill. 1993. The effect of germicides on the longevity of cut flowers. J. Amer. Soc. Hort. Sci. 118: 350354.

松川時晴. 1988. 園芸植物大事典 1. p. 499. 小学館. 東京. 農林水産省. 2018. 平成 28 年産花き生産出荷統計. 〈http:// www.e-stat.go.jp/stat-search/files?page $=1 \&$ layout $=$ datalist
$\& l i d=000001194863\rangle$.

小笠原 悠・市村一雄・福永哲也 - 永田晶彦 - 井上 守. 2012. 切り花の水揚げに関する生花店へのアンケート 調査扣よび水切りが主要切り花の吸水と品質保持に及 ぼす効果. 園学研. 11:577-583.

Put, H. M. C. and L. Jansen. 1989. The effects on the vase life of cut Rosa cultivar 'Sonia' of bacteria added to the vase water. Sci. Hortic. 39: 167-179.

佐藤昭二・後藤正夫・土井養二. 1983. 植物病理学実験 法. p. 94-95. 講談社サイエンティフィク。東京.

van Doorn, W. G., H. C. M. de Stigter, Y. de Witte and A. Boekestein. 1991. Micro-organisms at the cut surface and in xylem vessels of rose stems: A scanning electron microscope study. Journal of Applied Bacteriology 70: 34-39.

van Doorn, W. G. and Y. de Witte. 1994. Effect of bacteria on scape bending in cut Gerbera jamesonii flowers. J. Amer. Soc. Hort. Sci. 119: 568-571.

van Doorn, W. G., K. Schurer and Y. de Witte. 1989. Role of endogenous bacteria in vascular blockage of cut rose flowers. J. Plant Physiol. 134: 375-381.

van Meeteren, U. 1978. Water relations and keeping-quality of cut Gerbera flowers. I. The cause of stem break. Sci. Hortic. 8: $65-74$. 